Acknowledgment. This research was supported by PHS Grant CA28824. NMR spectra were obtained through the auspices of the Northeast Regional NSF/NMR Facility at Yale University, which was supported by NSF Chemistry Division Grant CHE 7916210. An N.I.H. Postdoctoral Fellowship to J.N.H. (Grant 1F32 CA08341-02) is gratefully acknowledged. In addition, we thank Dr. Nathan B. Mantlo of Merck Sharp \& Dohme Research Laboratories, Rahway, NJ for helpful discussions.

Supplementary Material Available: Spectral data (IR, ${ }^{1} \mathrm{H}$ NMR, and MS) for compounds 8-16, 18, and 20, tables of fractional coordinates, bond distances, torsional angles, and anisotropic temperature factors and summary of the $\mathrm{X}$-ray crystallographic determinations and structures of compounds $\mathbf{1 3}$ and 20 (17 pages). Ordering information is given on any current masthead page.

\section{Molecular Sieve Sensors for Selective Detection at the Nanogram Level}

Thomas Bein* and Kelly Brown

Department of Chemistry, University of New Mexico Albuquerque, New Mexico 87131

Gregory C. Frye and C. Jeffrey Brinker

Sandia National Laboratories, P.O. Box 5800 Albuquerque, New Mexico 87185

Received April 17, 1989

Zeolites have long been known for their molecular sieving properties based upon crystalline pore structures of molecular dimensions. ${ }^{1}$ We explore strategies to introduce molecular sieving functions into inorganic thin films and membranes which are of current interest for sensor coatings and gas-phase separations. ${ }^{2-4}$ The zeolite films offer high thermal stability $(>770 \mathrm{~K})$ and chemical resistance. Surface acoustic wave (SAW, Figure 1A) devices $^{5}$ can be operated as highly sensitive piezoelectric balances that respond to small fractions of single-crystal monolayer adsorption via frequency changes of an oscillator circuit. Since the response is nonselective, a number of organic and organometallic coatings on SAW devices have previously been explored to impart chemical selectivity. ${ }^{6}$ The SAW device ${ }^{7,8}(97 \mathrm{MHz}$, detection limit ca. $100 \mathrm{pg} / \mathrm{cm}^{2}$ ) used in the present study to measure selective adsorption of organic vapors $(0.1 \%$ of saturation in nitrogen flow, $295 \mathrm{~K}$ ) consists of a single-crystal quartz substrate with interdigital transducers which was coated with zeolite-silica thin films and mounted in a test chamber with gas inlet and outlet.

(1) Breck, D. W. Zeolite Molecular Sieves; Krieger: Malabar, FL, 1984

(2) Bein, T.; Brown, K.; Enzel, P.; Brinker, C. J. Mat. Res. Soc. Symp. Proc.; Materials Research Society: Pittsburgh, PA, 1988; Vol. 121, p 761

(3) Bein, T.; Brown, K.; Brinker, C. J. Studies in Surface Science and Catalysis (Zeolites: Facts, Figures, Future); Jacobs, P. A., van Santen, R. A., Eds.; Elsevier: Amsterdam, 1989; No. 49, p 887.

(4) Bein, T.; Brown, K.; Brinker, C. J. J. Non-Cryst. Solids, in press.

(5) (a) Wohltjen, H. Sens. Actuators 1984, 5, 307. (b) Venema, A.; Nieuwkoop, E.; Vellekoop, M. J.; Nieuwenhuizen, M. S.; Barendsz, A. W. Sens. Actuators 1986, 10, 47.

(6) (a) Wohltjen, H.; Snow, A. W.; Barger, W. R.; Ballantine, D. S. IEEE Trans. Ultrasonics, Ferroelectrics Freq. Contr. 1987, 34, 172. (b) Snow, A.; Wohltjen, H. Anal. Chem. 1984, 56, 1411. (c) Bryant, A.; Poirier, M.; Riley, G.; Lee, D. L.; Vetelino, J. F. Sens. Actuators 1983, 4, 105. (d) Nieuwenhuizen, M. S.; Barendsz, A. W. Sens. Actuators 1987, 11, 45. (e) Nieuwenhuizen, M. S.; Nederlof, A. J.; Barendsz, A. W. Anal. Chem. 1988, 60, 230.

(7) Frye, G. C.; Ricco, A. J.; Martin, S. J.; Brinker, C. J. Mat. Res. Soc. Symp. Proc.; Materials Research Society: Pittsburgh, PA, 1988; Vol. 121 , p 349 .

(8) Ricco, A. J.; Frye, G. C.; Martin, S. J. Langmuir 1989, 5, 273.

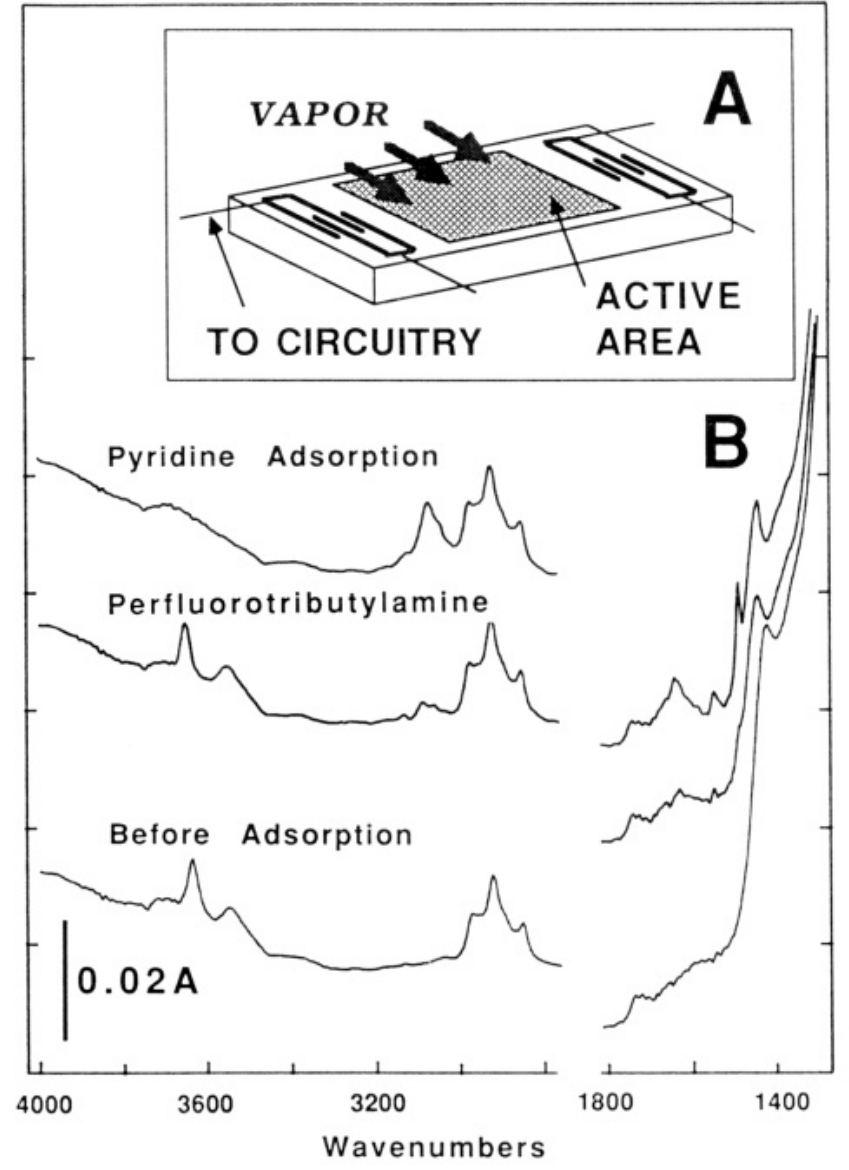

Figure 1. A. Schematics of the surface acoustic wave device. B. Adsorption of pyridine and perfluorotributylamine vapor (1 Torr at $295 \mathrm{~K}$ ) on HY-zeolite film embedded in silica matrix derived from base-catalyzed sol (B2), degassed at $570 \mathrm{~K}, 10^{-7}$ Torr. FTIR spectra were taken at $8-\mathrm{cm}^{-1}$ resolution in a stainless steel $\mathrm{UHV}$ cell, equipped with $\mathrm{CaF}_{2}$ windows and connected to a steel apparatus with turbomolecular pump and mass spectrometer. The features in the $\mathrm{C}-\mathrm{H}$ stretch region (ca. $2800-3000 \mathrm{~cm}^{-1}$ ) are due to decomposition products of the sol matrix deposited on the cell windows after initial heating.

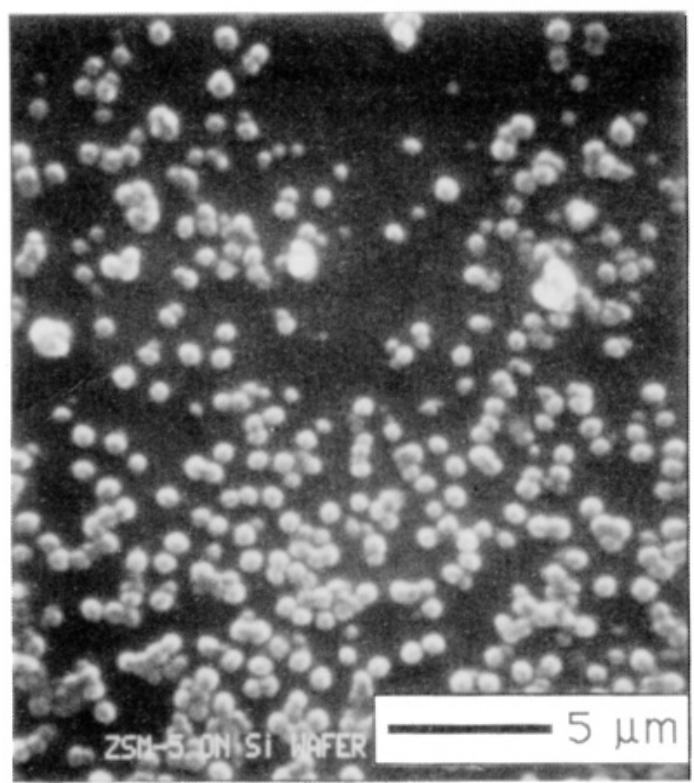

Figure 2. Scanning electron micrograph of crystals of zeolite H-ZSM-5 embedded in an A2-sol derived matrix ${ }^{16}$ on a Si wafer.

The zeolite-silica composites are prepared from suspensions of small zeolite crystals in alcoholic solutions of tetraethylorthosilicate (TEOS) that is hydrolyzed and polymerized by acid- and basecatalyzed reactions resulting in extended, weakly branched 
structures or compact, colloidal particles, respectively.,10 During deposition of the zeolite/silicate suspensions by dip-coating, the solvent is evaporated, and the silicate films gel, "freezing in" the incorporated zeolite crystals (Figure 2). Final consolidation of the porous matrix structure to a nonporous film occurs by viscous sintering. ${ }^{11,12}$

The molecular sieving behavior of zeolite $\mathrm{Y}^{13}$ (Y, crystal size, $0.2 \mu \mathrm{m}$; pore size, $7.5 \AA$ ), chabazite ${ }^{14}$ (CHA, crystal size, $1-3 \mu \mathrm{m}$; pore size, $3.7 \AA$ ), $\mathrm{ZSM}^{-5^{15}}$ (crystal size, $0.5 \mu \mathrm{m}$; pore size, 5.4 $\times 5.6 \AA$ ), and zeolite A (LTA, crystal size, $3 \mu \mathrm{m}$; pore size, 4.1 $\AA$ ) crystals is maintained when they are embedded in TEOS sol-gel derived glassy thin films. ${ }^{16,17}$ For example, the acid form of zeolite $\mathrm{Y}^{18}$ embedded in a silicate-based film adsorbs pyridine $(5.9 \AA$ kinetic diameter) as shown by consumption of the intrazeolite bridged hydroxyl groups (at 3540 and $3640 \mathrm{~cm}^{-1}$ ) and the formation of pyridinium ions (band at $1545 \mathrm{~cm}^{-1}$; Figure 1B). However, exposure of a similar film to perfluorotributylamine $(10.2 \AA)$ does not indicate any reaction with the internal bridged hydroxyls. Similarly, acidic chabazite-based films (pore size 3.7 $\AA$ ) react with ammonia $(2.6 \AA)$ but not with tributylamine $(8.1$ $\AA$ ).

The selectivity of zeolite films is maintained even in aqueous systems. For example, pyridine or $\mathrm{NH}_{3}$ diffused into $\mathrm{Cu}(\mathrm{II})$ containing faujasite-silica thin films ${ }^{19}$ from aqueous solution coordinate to intrazeolite $\mathrm{Cu}$ (II) to form $\left[\mathrm{CuL}_{4}\right]^{2+}$ complexes as shown by the appearance of corresponding ligand vibrations, e.g., at $1610,1543,1487$, and $1450 \mathrm{~cm}^{-1}$ for $\left[\mathrm{Cu}(\mathrm{py})_{4}\right]^{2+}$. When CHA $(3.7 \AA)$ or LTA $(4.1 \AA)$ are incorporated in the glassy matrix, pyridine is completely excluded from the pores. In aqueous phase, the pyridine molecules bind selectively to $\mathrm{Cu}$-FAU films but not to the corresponding $\mathrm{Na}$ or $\mathrm{NH}_{4}$ forms.

Having demonstrated the chemical and size-based molecular selectivity of zeolite-silica films, we present the first application of these films as coatings on SAW devices. We note that thin silica films alone, processed similarly, have extremely low porosity $(<2 \%)$ and surface areas $\left(1 \mathrm{~cm}^{2} / \mathrm{cm}^{2}\right){ }^{8}$ A glassy silica matrix of ca. $150 \mathrm{~nm}$ thickness, embedding crystals of ZSM-5 (pore size $5.4 \times 5.6 \AA$ ), was coated on the active surface of a SAW device. A striking difference in frequency response to different probe molecules was observed. While vapors of $\mathrm{MeOH}$ (ca. $3.8 \AA$ kinetic diameter) and $\mathrm{PrOH}$ (ca. $4.7 \AA$ ) adsorb at levels of 500-800 $\mathrm{ng} / \mathrm{cm}^{2}$ in the film, the response to isooctane $(2,2,4$-trimethylpentane; $6.2 \AA$ ) is minimal (below $5 \mathrm{ng} / \mathrm{cm}^{2}$ ). This dramatic difference can be understood if the kinetic diameters of these molecules are compared to the pore size of the zeolite film. The amount of vapor adsorbed in the film is in reasonable agreement with that calculated from crystal area densities observed in electron micrographs.

(9) Brinker, C. J.; Keefer, K. D.; Schaefer, D. W.; Ashley, C. S. J. NonCryst. Solids 1982, 48, 47.

(10) Brinker, C. J.; Scherer, G. W. J. Non-Cryst. Solids 1985, 70, 301.

(11) Brinker, C. J.; Scherer, G. W.; Roth, E. P. J. Non-Cryst. Solids 1985, 72,369 .

(12) Brinker, C. J.: Drotning, W. D.; Scherer, G. W. In Better Ceramics through Chemistry; Brinker, C. J., Clark, D. E., Ulrich, D. R., Eds.; Elsevier: Amsterdam, 1984; p 25

(13) Synthesized according to U.S. Patent 4,175,059, 1979, example 3.

(14) Synthesized according to ref $1, p 288$

(15) Synthesized according to van Santen, R. A.; Keijsper, J.; Ooms, G.; Kortbeek, A. G. T. G. In New Developments in Zeolite Science and Technology: Murakami, Y., Iijima, A., Ward, J. W., Eds.; Kodansha: Tokyo, Japan, 1986; p 169.

(16) Silica sols were prepared from a stock solution of $61.0 \mathrm{~mL}$ of TEOS (tetraethylorthosilicate), $61.0 \mathrm{~mL}$ of EtOH, and $5.0 \mathrm{~mL}$ of $0.04 \mathrm{M} \mathrm{HCl}$. For the preparation of $\mathrm{A} 2 \mathrm{sol}, 10 \mathrm{~mL}$ of the stock solution was combined with 0.12 $\mathrm{mL}$ of $1.0 \mathrm{M} \mathrm{HCl}$ and $0.4 \mathrm{~mL}$ of $\mathrm{H}_{2} \mathrm{O}$. B2 sol was obtained by adding 1.0 $\mathrm{mL}$ of $0.05 \mathrm{M} \mathrm{NH}_{4} \mathrm{OH}$ to $10 \mathrm{~mL}$ of the stock solution. See: Brinker C. J. Keefer, K. D.; Schaefer, D. W.; Assink, R. A.; Kay, B. D.; Ashley, C. S. J. Non-Cryst. Solids $1984,63,45$.

(17) Dip-coated composites were made from suspensions of $0.5-2.5 \mathrm{~g}$ zeolite in $2.5 \mathrm{~mL}$ of silica sol which was diluted with $5 \mathrm{~mL}$ of EtOH and coated on Si wafers at $50 \mathrm{~mm} / \mathrm{min}$ vertical pulling rate. All wafers were dried in air at $360 \mathrm{~K}$

(18) Obtained by degassing the $\mathrm{NH}_{4}$-exchanged form at $670 \mathrm{~K}$ in vacuo.

(19) Zeolites were $50 \%$ ion-exchanged with $0.1 \mathrm{M} \mathrm{Cu}\left(\mathrm{NO}_{3}\right)_{2}$ prior to dispersion in the sol
We have established that (i) zeolite-silica thin films with molecular sieving properties can be prepared, (ii) the films can be modified such that different chemical selectivities result, and (iii) these zeolite films can be utilized to introduce chemical selectivity to highly sensitive surface acoustic wave devices. Other zeolite thin film coatings with modified chemical selectivities are presently being explored.

Acknowledgment. Financial support from the National Science Foundation (DMR-8706167) is gratefully acknowledged. A portion of the work was performed at Sandia National Laboratories and supported by the U.S. Department of Energy under contract number DE-AC-04-76DP00789. We appreciate the technical assistance of Barbara Lammie.

\section{Novel Anionic Polymerization of Masked Disilenes to Polysilylene High Polymers and Block Copolymers ${ }^{1}$}

Kenkichi Sakamoto, Kuninori Obata, Hiroki Hirata, Masashi Nakajima, and Hideki Sakurai*

Department of Chemistry, Faculty of Science Tohoku University, Aoba-ku, Sendai 980, Japan

Received February 8, 1989

Polysilylenes, the linear silicon-silicon bonded polymers, have several interesting properties and are a subject of current intense investigations. $^{2}$ Polysilylenes are prepared mostly by the Wurtz-type coupling reactions of dichlorodialkylsilanes which, however, have several difficulties such as the poor control of structure, molecular weight, and polydispersity. The yields of polymers are also usually low.? In this paper, we will describe an entirely novel method of preparing polysilylenes based on anionic polymerization of masked disilenes.

After examination of several possibilities, we have found that 1-phenyl-7,8-disilabicyclo[2.2.2] octa-2,5-dienes (1b-1d) can be used for anionic polymerization. ${ }^{13}$ Alkyllithiums such as $n$ - and

(1) Chemistry of Organosilicon Compounds 257

(2) (a) West, R. J. Organomet. Chem. 1986, 300, 327. (b) West, R. Organopolysilanes. In Comprehensive Organometallic Chemistry; Abel, E., Ed.; Pergamon: Oxford, England, 1982; Chapter 9.4, pp 365. Recent applications of polysilylenes as $\mathrm{SiC}$ precursors, ${ }^{3}$ in microlithography, ${ }^{4}$ as photoinitiators, ${ }^{5}$ and in reprography ${ }^{6}$ are noteworthy.

(3) (a) Yajima, S.; Hayashi, J.; Omori, M. Chem. Lett. 1975, 931. (b) Yajima, S.; Shishido, T.; Kayano, H. Nature 1976, 264, 237. (c) Yajima, S. Omori, M.; Hayashi, J.; Okamura, K.; Matsuzawa, T.; Liaw, C. Chem. Lett 1976, 551. (d) West, R.; David, L. D.; Djurovich, P. I.; Yu, H.; Sinclair, H Am. Ceram. Soc. Bull. 1983, 62, 899 .

(4) (a) Gobbi, G. C.; Fleming, W. W.; Sooriyakumaran, R.; Miller, R. D. J. Am. Chem. Soc. 1986, 108, 5624. (b) West, R; Wolff, A. R.; Peterson, D. J. Radiation Curing 1986, 13,35 .

(5) Wolff, A. R.; West, R. Appl. Organomet. Chem. 1987, 1, 7.

(6) Abkowitz, M.; Knier, F. E.; Yuh, H.-J.; Weagley, R. J.; Stolka, M. Solid State Commun 1987, 62, 547 .

(7) A few other routes are indicated for the preparation of polysilylenes such as catalyzed dehydrogenative coupling of primary organosilanes, but at this moment the method is limited to the preparation of low molecular weight oligomers of arylsilanes. ${ }^{8}$

(8) (a) Aitkin, C. T.; Harrod, J. F.; Samuel, E. J. Organomet. Chem. 1985 279, C11. (b) Aitkin, C. T.; Harrod, J. F.; Samuel, E. J. Am. Chem. Soc. 1986, 108, 4095. (c) Aitkin, C. T.; Harrod, J. F.; Samuel, E. Can. J. Chem. $1986,64,1677$.

(9) Conceptually, polymerization of disilenes, the silicon-silicon double bonded species, may be a straightforward route to linear polysilylenes. It is not possible in practice though, because disilenes are not stable enough to be isolated except for those with very bulky substituents. ${ }^{10}$ Incidentally, 7,8 disilabicyclo[2.2.2] octa-2,5-dienes have been known as precursors of disilenes: Roark and Peddle ${ }^{11}$ reported generation of disilenes by thermolysis of 1a. We have also reported that a 2,3-benzo-7,8-disilabicyclo[2.2.2]octa-2,5-diene system afforded cis- and trans-1,2-diphenyl-1,2-dimethyldisilenes by thermolysis. ${ }^{12}$ Therefore, we have expected that these 7,8-disilabicyclo[2.2.2]octa-2,5-diene systems could behave as masked disilenes even in ionic reactions.

(10) (a) West, R.; Fink, M. J.; Michl, J. Science (Washington, D. C.) 1981 214,1343 (b) Masamune, S - Hanzawa, Y. Murakami, S.; Bally, T. Blout J. F. J. Am. Chem. Soc. 1982, 104, 1150 